\title{
PENGARUH METODE INQUIRI TERHADAP KEMAMPUAN BERPIKIR KREATIF MATEMATIK SISWA SMAN 1 MANDE KAB. CIANJUR
}

\author{
ABDUL JALALUDIN \\ Pascasarjana PMIPA, Universitas Indraprasta PGRI, Jakarta \\ e-mail: jalaludin.16@gmail.com
}

\begin{abstract}
ABSTRAK
Penelitian ini merupakan penelitian eksperimen yang difokuskan pada peningkatan kemampuan berpikir kreatif matematik siswa SMA dengan menerapkan metode pembelajaran inquiri. Masalah yang melatar belakangi penelitian ini adalah kurang dibiasakanya pembelajaran menggunakan metode dengan pemusatan pembelajaran pada siswa sebagai cara untuk memperoleh pengalaman belajar yang lebih bermakna dengan dilandasi kemampuan berpikir kreatif siswa berbeda pada setiap siswa. Tujuan penelitian ini adalah : 1) Untuk mengetahui pengaruh metode pembelajaran inquiri terhadap kemampuan berpikir kreatif matematik siswa. 2) untuk mengetahui perbandingan peningkatan kemampuan berpikir kreatif matematik siswa menggunakan metode pembelajaran inquiri dengan pembelajaran konvensional; 3) untuk mengetahui sikap siswa terhadap pembelajaran metode inquiri. Penelitian ini menggunakan metode eksperimen desain "desain countrol group pretes-postes", yang dilakukan di kelas X SMA Negeri 1 Mande Cianjur yang berjumlah 5 rombongan belajar dengan sampel kelas eksperimen adalah kelas X-4 dan sampel kelas kontrol adalah kelas X-3. Indikator kemampuan berpikir kreatif matematik yang diukur dalam penelitian ini adalah: 1) kemampuan mengganti (Substitute), mengkombinasi (Combine), menyesuaikan (Adapt), memodifikasi (Magnify/Modify), untuk kegunaan lain (Put to other use), Menghapus (Eliminate) dan menyusun kembali (Rearrange/Reverse) dari kemampuan yang telah ada; 2) kemampuan menyusun kembali kemampuan/membalik yang telah ada dengan keluwesan (mencoba hal baru), keaslian (menjawab cara sendiri) dan menguraikan (mengembangkan ide) dalam memahami suatu hal. Hasil penelitian menunjukkan bahwa: 1) metode pembelajaran inquiri memiliki pengaruh terhadap kemampuan berpikir kreatif matematik siswa; 2) metode pembelajaran inquiri memiliki peningkatan berpikir kreatif matematik siswa yang lebih baik dari pada metode konvensional; 3) siswa memiliki sikap positif terhadap metode pembelajaran inquiri.
\end{abstract}

Kata Kunci: Metode inquiri, berpikir kreatif matematik

\section{ABSTRACT}

This research is an experimental study that focuses on increasing the mathematical creative thinking skills of high school students by applying the inquiry learning method. The problem behind this research is the lack of familiarity with learning using methods with a focus on learning on students as a way to get a more meaningful learning experience based on students' creative thinking skills that are different for each student. The aims of this study are: 1) To determine the effect of the inquiry learning method on students' mathematical creative thinking skills. 2) to find out the comparison of increasing students' mathematical creative thinking skills using the inquiry learning method with conventional learning; 3 ) to determine students' attitudes towards learning the inquiry method. This study used the experimental design method "design control group pretest-posttest", which was carried out in class X SMA Negeri 1 Mande Cianjur which consisted of 5 study groups with the experimental class sample being class X-4 and the control class sample being class X-3. The indicators of mathematical creative thinking skills measured in this study are: 1) the ability to replace (Substitute), combine (Combine), adjust (Adapt), modify (Magnify/Modify), for other uses (Put to other use), Delete (Eliminate). ) and rearrange (Rearrange/Reverse) from existing capabilities; 2 ) the ability to rearrange existing abilities/reverse with flexibility (trying new things), authenticity (answering their own way) and outlining (developing ideas) in understanding something. The results showed that: 1 ) the inquiry 


\section{SCIENCE : Jurnal Inovasi Pendidikan Matematika dan IPA Vol. 1 No. 3 November 2021 e-ISSN : 2797-1031 | p-ISSN : 2797-0744}

learning method had an influence on students' mathematical creative thinking abilities; 2) the inquiry learning method has an improvement in students' mathematical creative thinking which is better than the conventional method; 3) students have a positive attitude towards the inquiry learning method.

Keywords: Inquiry method, mathematical creative thinking

\section{PENDAHULUAN}

Pendidikan merupakan tonggak akan terciptanya pengetahuan yang kemudian disusun menjadi suatu ilmu pengetahuan yang dijadikan modal untuk menjalani hidup, prosesnya dapat diperoleh dengan cara pengalaman sendiri atau yang sering disebut belajar dan diperoleh dengan cara bersekolah yaitu pembelajaran. Untuk itu pendidikan haruslah dilaksanakan secara baik dan juga benar agar manusia dapat hidup seutuhnya sehingga bermanfaat dan berguna dalam melaksanakan kehidupan. Hal ini sejalan dengan makna pendidikan yang tercantum dalam UU SISDIKNAS No. 20 pasal 1 ayat 1 tahun 2003 yakni usaha yang sadar dan terencana untuk mengembangkan potensi dirinya.

Sejalan dengan pengertian kemampuan sesuatu yang dijadikan siswa dalam proses belajar haruslah bermakna siswa dalam hal ini dituntut untuk mampu memecahkan masalah. Sebab ketika sudah terjun dilingkungan masyarakat siswa menjadi lebih harus memiliki kemampuan yang analitis dalam berpikir dan menyelesaikannya denga kreatif mungkin. Oleh karena itu pembelajaran akan lebih bermakna, pembelajaran tersebut seharusnya lebih menekan pada peserta didik untuk dapat mengalami dan merasakan sehingga peserta didik mendapat pengalaman dari pembelajaran tersebut. Dan juga rasa malas di mungkinkan seorang guru kurangnya bervariasi dalam mengunakan metode pembelajaran atau metode apa yang digunakan guru. Sejalan akan hal itu sehingga siswa mengalami kesalahan dimungkinkan kurangnya pengalaman dan pengetahuan bagaimana metode yang di dekati untuk menyelesaian masalah terutama dalam hal pengerjaan soal yang biasanya siswa tahu prosedurnya saja akan tetapi pemahamanya kurang sehingga siswa cenderung menghasilkan hasil belajar yang kurang baik terutama dari hal kreatif siswa berkurang dan ketika menemui soal yang bentuknya berbeda dengan contoh soal siswa sulit mengerjakannya, untuk itu perlu metode yang dituntut siswa biasa menyelesaikan soal dengan cara sendiri agar berpikir kreatif meningkat dan hasil belajar juga meningkat.

Metode yang sering digunakan guru sebagian besar berbentuk konvensional yang sering menitik beratkan pada kegiatan satu arah yaitu metode ceramah yang guru di jadikan pusat pembelajaran, sehingga siswa kurang menjadi aktif yang biasanya masuk telinga kiri keluar telinga kanan dan ketika keluar kelas siswa bingung apa yang dipelajari tadi di kelas. Selain itu juga siswa tidak memahami materi karena siswa hanya bisa menghapal saja yang diberikan guru. Proses pembelajaran pun di rasa kurang bermakna karena siswa tidak mengalami menemukan sendiri dan kreativitas pun berkurang karena tidak diberikan banyak kebebasan.Menurut teori belajar kognitif, belajar merupakan suatu proses terpadu di dalam diri seseorang dalam upaya memperoleh pemahaman dan struktur kognitif baru atau untuk mengubah pemahaman dan struktur yang lama. Ketercapaian proses belajar tersebut sepatutnya dilakukan secara aktif melalui berbagai kegiatan, seperti memahami, melakukan, mencari dan menemukan keaktifan belajar sebagai prasyarat diperolehnya hasil belajar. (Sumiati dan Asra, 2007:47 )

Untuk itu perlu ada pembelajaran yang menggunakan metode yang hanya menjadikan siswa sebagai pusat pembelajaran. Menurut Sumiati dan Asra (2007:39) "suatu proses belajar harus bersifat praktis dan langsung, artinya jika seseorang ingin mempelajari sesuatu, maka dia sendirilah yang harus melakukannya, tanpa melalui perantara orang lain". Dengan pembelajaran seperti ini siswa diharapkan dapat memahami konsep, karena mengalami sendiri kemudahan dan kesulitan yang di alami dalam mempelajari konsep, sehingga akan teringat secara melekat dalam waktu yang lama di memori otak. Kemampuan dalam berpikir kreatif pun 
di tuntut untuk memahami konsep tersebut sehingga kegiatan pembelajaran pun di rasa akan lebih bermakna bagi siswa.

Dari pengalaman praktik mengajar di sekolah (Agustus - Desember 2011) kebiasan tersebut masih ada, yang kemudian peneliti mengambil asumsi bahwa apa yang dialami sendiri oleh siswa membuat belajar lebih bermakna karena siswa menemukan sendiri apa yang menjadi pokok pembelajaran dan kesulitannya sehingga siswa berupaya menyelesaikan masalah yang di hadapi dengan berpikir bagaimana cara menyelesaikannya, dari hal itu peneliti mengambil judul " pengaruh metode inquiri terhadap kemampuan berpikir kreatif matematik siswa SMAN 1 Mande Kabupaten Cianjur"

\section{METODE PENELITIAN}

Penelitian ini mengkaji hubungan dua variabel, yaitu metode inquiry sebagai variabel $\mathrm{X}$ dan kemampuan berpikir kreatif variabel Y. Dalam penelitian ini akan dilihat perbedaan ratarata kemampuan berpikir kreatif siswa yang menggunakan metode pembelajaran inquiry dengan siswa yang menggunakan metode pembelajaran konvensional. Desain yang digunakan dalam penelitian ini adalah desain countrol group pretest-postes pada kedua kelompok. Desain penelitiannya dengan pola sebagai berikut :

$$
\begin{aligned}
& \begin{array}{lllll}
\mathrm{E}: & \mathrm{A} & \mathrm{O}_{1} & \mathrm{X}_{1} & \mathrm{O}_{2}
\end{array} \\
& \begin{array}{llllll}
\mathrm{K}: & \mathrm{A} & \mathrm{O}_{2} & \mathrm{X}_{2} & \mathrm{O}_{2} & \text { (Arikunto,2010:125) }
\end{array} \\
& \text { Keterangan : } \\
& \mathrm{E} \quad=\text { Kelompok Eksperimen } \\
& \mathrm{K} \quad=\text { Kelompok Kontrol } \\
& \text { A } \quad=\text { Sampel Acak } \\
& \mathrm{O}_{1} \quad=\text { Pretest } \\
& \mathrm{O}_{2} \quad=\text { Postest } \\
& \mathrm{X}_{1} \quad=\text { Pembelajaran dengan menggunakan metode pembelajaran Inquiri pada } \\
& \text { kelas eksperimen } \\
& \mathrm{X}_{2} \quad=\text { Pembelajaran dengan menggunakan metode pembelajaran konvensional } \\
& \text { pada kelas kontrol }
\end{aligned}
$$

Penelitian ini adalah penelitian eksperimen yang sifatnya studi yakni studi eksperimen yang dilaksanakan di SMA Negeri 1 Mande Cianjur dengan populasi kelas X pada tahun ajaran 2012/213 dengan 5 jumlah rombongan belajar, sampel yang digunakan untuk kelas eksperimen kelas X-4 dan sampel kelas kontrol kelas X-3.

Pada penelitian ini dalam pengumpulan data menggunakan jenis instrumen tes dan non tes. Untuk instrumen jenis tes adalah tes kemampuan berpikir kreatif matamatik sedangkan untuk instrumen jenis nontes berupa angket skala sikap. Pengolahan data yang diperoleh menggunakan program SPSS 17.0 dan uji coba tes untuk mengetahui validitas, reliabilitas, daya pembeda, dan tingkat kesukaran menggunakan Anates Versi 4.0, dan untuk pengolahan angket dibuat persentase modus. Berikut alur pengolahan data yang dilakukan (Yohanes Anton Nugroho,2011) yaitu:

$$
\begin{array}{ll}
\text { - } & \text { Data } \rightarrow \text { Normal } \rightarrow \text { Homogen } \rightarrow \text { Independent Sampel T Test } \\
\text { - } \quad & \text { Data } \rightarrow \text { Normal } \rightarrow \text { Tidak Homogen } \rightarrow \text { Independent Sampel T' Test } \\
& \text { Data } \rightarrow \text { Tidak Normal } \rightarrow \text { Non Prametik (Uji Mann whitney) }
\end{array}
$$

\section{HASIL DAN PEMBAHASAN}

\section{Hasil}

1. Data Hasil Pretes

Analisis deskriftif statistik untuk menggetahui kemampuan awal siswa pada kedua kelas yang diperlihatkan pada tabel 1 . 
Tabel 1. Deskriftif Statistik Pretes

\begin{tabular}{lccccc}
\hline Kelas & $\mathbf{N}$ & $\boldsymbol{X}_{\text {min }}$ & $\boldsymbol{X}_{\text {mak }}$ & Mean & Standar deviasi \\
\hline Eksperimen & 31 & 10 & 65 & 32,65 & 12,661 \\
\hline Kontrol & 30 & 6 & 29 & 17,20 & 5,385 \\
\hline
\end{tabular}

Uji normalitas distribusi populasi menggunakan uji kolmogorof-Smirnov. Setelah di uji ternyata hanya kelas eksperimen berdistribusi normal dan kelas kontrol tidak berdistribusi normal sehingga dilanjutkan dengan statistik nonparametik menggunakan uji Man-Whitney. Setelah diuji ternyata terdapat perbedaan rata-rata kemampuan awal berpikir kreatif matematik siswa.hasil analisis diperlihatkan tabel berikut menggunakan $\alpha=0,05$

\begin{tabular}{|c|c|}
\hline $\begin{array}{c}\text { Tabel 2. Uji SigI } \\
\text { uji kolmogorof- } \\
\text { Smirnov. }\end{array}$ & Sig. \\
\hline Eksperimen & 0,200 \\
\hline Kontrol & 0,036 \\
\hline \multicolumn{2}{|c|}{ uji Man-Whitney } \\
\hline Sig (2-tailed) & 0,000 \\
\hline
\end{tabular}

Karena data memiliki perbedaan kemampuan awal berpikir kreatif matematik siswa pada kedua kelas, dilanjutkan analisis Gain bukan analisis Postes dalam menganalis peningkatan.

2. Data Hasil indeks Gain

Data indeks gain digunakan untuk mengetahui peningkatan kemampuan berpikir kreatif matematik siswa.data terlebih dahulu dihitung dengan rumus indeks gain pada kedua kelas, berikut hasil indeks gain yang diperoleh diperlihatkan oleh tabel 3, dan deskriptif satatistik pada tabel 4.

Tabel 3. Hasil Indeks Gain

\begin{tabular}{ccc}
\hline Sifat & \multicolumn{2}{c}{ Kelas } \\
\cline { 2 - 3 } Peningkatan & Eksperimen & Kontrol \\
\hline Rendah & 19 orang & 7 orang \\
\hline Sedang & 11 orang & 23 orang \\
\hline Tinggi & 1 orang & $\begin{array}{c}\text { Tidak } \\
\text { seorangpun }\end{array}$ \\
\hline
\end{tabular}

Tabel 4. Deskriftif Statistik Indeks Gain

\begin{tabular}{cccccc}
\hline Kelas & $\mathbf{N}$ & $\boldsymbol{X}_{\text {min }}$ & $\boldsymbol{X}_{\text {mak }}$ & Mean & Standar deviasi \\
\hline Eksperimen & 31 & 0,0 & 0,73 & 0,2874 & 0,21621 \\
\hline Kontrol & 30 & 0,13 & 0,68 & 0,4173 & 0,13851 \\
\hline
\end{tabular}

Tabel 5. Uji Signifikasi Data Hasil Indeks Gain

\begin{tabular}{lc}
\hline $\begin{array}{l}\text { uji kolmogorof- } \\
\text { Smirnov. }\end{array}$ & Sig. \\
\hline Eksperimen & 0,200 \\
\hline Kontrol & 0,066 \\
\hline \multicolumn{2}{c}{ uji Levene } \\
\hline Sig. & 0,009 \\
\hline \multicolumn{2}{c}{ uji Independen Sampel T' Test } \\
\hline Sig (2-tailed) & 0,007 \\
\hline
\end{tabular}


Uji normalitas distribusi populasi menggunakan uji kolmogorof-Smirnov. Setelah di uji ternyata kedua kelas berdistribusi normal. Dilanjutkan uji homogenitas mennggunakan uji Levene, Setelah diuji ternyata data berasal dari populasi yang memiliki tidak varian yang sama atau tidak homogen. Kemudian dilanjutkan dengan uji kesamaan dua rata-rata menggunakan uji Independen Sampel T' Test, dengan hasil menunjukan kemampuan berpikir kreatif matematik dengan metode pembelajaran inquiri lebih meningkat dari pada metode pembelajaran konvensional.hasil analisis diperlihatkan tabel berikut menggunakan $\alpha=0,05$.

3. Data Hasil Angket

Data ini digunakan untuk mengetahui sikap siswa terhadap metode pembelajaran yang telah dilakukan, berikut hasil yang diperoleh dengan menghitung persentase pernyataan yang dipilih yang diperlihatkan oleh tabel 6.

Tabel 6. Sikap Siswa terhadap keseluruhan pernyataan

\begin{tabular}{cc}
\hline Sikap & Jumlah \\
\hline Positif & 18 \\
\hline Netral & 8 \\
\hline Negatif & 4 \\
\hline
\end{tabular}

Tabel 7. Persentase Sikap siswa Berdasarkan Bentuk Pernyataan

\begin{tabular}{|c|c|c|c|c|}
\hline Sifat & Sikap & $(\%)$ & $\begin{array}{c}\text { Sikap } \\
(\%)\end{array}$ & Sikap \\
\hline \multirow{5}{*}{ 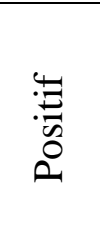 } & SS & 11,6 & \multirow{2}{*}{62,0} & \multirow{5}{*}{ 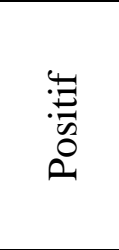 } \\
\hline & $S$ & 40,4 & & \\
\hline & $\mathrm{N}$ & 32,2 & 32,2 & \\
\hline & $\mathrm{TS}$ & 13,9 & \multirow{2}{*}{15,8} & \\
\hline & STS & 1,9 & & \\
\hline \multirow{5}{*}{ 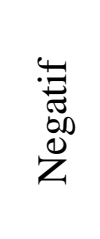 } & SS & 13,6 & \multirow{2}{*}{38,4} & \multirow{5}{*}{ 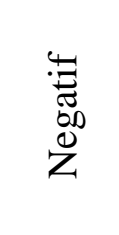 } \\
\hline & $S$ & 24,8 & & \\
\hline & $\mathrm{N}$ & 34,4 & 34,4 & \\
\hline & $\mathrm{TS}$ & 24,8 & \multirow{2}{*}{27,0} & \\
\hline & STS & 2,2 & & \\
\hline
\end{tabular}

Tabel 8. Persentase Sikap siswa Berdasarkan Indikator

\begin{tabular}{|c|c|c|c|c|}
\hline No & Indikator & $\begin{array}{r}\text { Rata } \\
\text { Perse } \\
(9 \\
\end{array}$ & $\begin{array}{l}\text { rata } \\
\text { itase } \\
\end{array}$ & $\begin{array}{c}\text { Rata- } \\
\text { Rata } \\
(\%) \\
\end{array}$ \\
\hline \multirow{3}{*}{1.} & Terhadap & + & - & \multirow{9}{*}{43,79} \\
\hline & Mata & 27,42 & 17,7 & \\
\hline & Pelajaran & \multicolumn{2}{|c|}{45,12} & \\
\hline \multirow{3}{*}{2.} & Terhadap & + & - & \\
\hline & Metode & 21,64 & 21,37 & \\
\hline & Pembelajaran & \multicolumn{2}{|c|}{43,01} & \\
\hline \multirow{3}{*}{3.} & \multirow{3}{*}{$\begin{array}{c}\text { Terhadap } \\
\text { Kemampuan } \\
\text { Berpikir } \\
\text { Kreatif }\end{array}$} & + & - & \\
\hline & & 28,75 & 14,5 & \\
\hline & & \multicolumn{2}{|c|}{43,25} & \\
\hline
\end{tabular}

4. Data Hasil Angket dan Data Hasil Indeks Gain

Analisis ini digunakan untuk mengetahui besar pengaruh yang diperoleh dari hasil perlakuan, data angket dirubah dahulu menjadi kuantitatif yang diperlihatkan oleh tabel 9. 


\section{Tabel 9. Korelasi Hasil Angket dengan Hasil Indeks Gain \\ Besar korelasi \\ $-0,087$}

\section{Pembahasan}

1. Analisis dan Pembahasan Data Hasil Pretes.

Pada Tabel 1, menunjukan bahwa rata-rata pretes pada kelas eksperimen 32,65 dan kelas kontrol 17,20. Sehingga kelas eksperimen memiliki nilai lebih tinggi, yang artinya kemampuan awal kedua kelas berbeda.

2. Analisis dan Pembahasan Data Hasil indeks Gain

Analisis gain digunakan untuk mengetahui peningkatan kemampuan berpikir kreatif matematik siswa.data terlebih dahulu dihitung dengan rumus indeks gain pada kedua kelas, Maka digunakan penghitungan indeks gain dengan rumus indeks gain menurut Meltzer dalam Kurniadi (rahayu,2009:37) sebagai berikut:

$$
\text { Indeks gain }=\frac{\text { Skor posttes }- \text { skor pretest }}{\text { SMI-skor pretest }}
$$

Menurut Hake dalam Yulianti (Rahayu, 2009:37) sebagai berikut

Tabel 10. Interpretasi Indeks gain

\begin{tabular}{cc}
\hline Indeks Gain $(\mathrm{G})$ & Interpretasi \\
\hline $\mathrm{G}>0,7$ & Tinggi \\
\hline $0,3<\mathrm{G} \leq 0,7$ & Sedang \\
\hline $\mathrm{G} \leq 0,3$ & Rendah
\end{tabular}

Dengan hasil indeks gain yang diperoleh diperlihatkan oleh tabel 3, dan deskriptif satatistik pada tabel 4. Dari tabel 3 menunjukan sifat peningkatan kedua kelas hampir sebanding dengan membandingkan satu persatu sifat peningkatan untuk rendah dan sedang memiliki selisih perbedaan 12 orang akan tetapi untuk tinggi kelas eksperimen lebih baik, itu artinya kelas eksperimen memiliki peningkatan. Akan tetapi jika melihat hasil dari tabel 4 menunjukan rata-rata peningkatan kelas eksperimen 0,2874 dan kelas kontrol 0,4173, sehingga nilai ratarata peningkatan kelas kontrol lebih tingi dibandingkan dengan kelas eksperimen. Itu artinya tidak ada peningkatan.

3. Analisis dan Pembahasan Data Hasil Angket

Analisis ini digunakan untuk mengetahui sikap siswa terhadap metode pembelajaran yang telah dilakukan. Menurut ( Partino dan Idrus, 2009 ) untuk menganalisis angket dengan cara mencari persentasi setiap aspek yang dinilai dengan rumus sebagai berikut:

$$
\mathrm{P}=\frac{f}{n} \times 100 \%
$$

Klasifikasi interpretasi perhitungan pesentase jawaban menurut Kuntjaraningrat (Rahayu, 2009:36) yaitu sebagai berikut:

Tabel 11 Inpretasi Persentase Jawaban

\begin{tabular}{cc}
\hline Persentase jawaban & Interpretasi \\
\hline $\mathrm{P}=0$ & Tak seorangpun \\
\hline $0<\mathrm{P} \leq 25$ & Sebagian Kecil \\
\hline $25<\mathrm{P}<50$ & Hampir Setengahnya \\
\hline $\mathrm{P}=50$ & Setengahnya \\
\hline
\end{tabular}




\begin{tabular}{cc}
\hline $50<\mathrm{P} \leq 75$ & Sebagian Besar \\
\hline $75<\mathrm{P}<100$ & Hampir Seluruhnya \\
\hline $\mathrm{P}=100$ & Seluruhnya \\
\hline
\end{tabular}

Adapun untuk mengetahui sikap siswa bersikap positif atau tidak dihitung dengan jumlah persentase terbesar dengan penghitungan sebagai berikut:

Tabel 12 Sikap Siwa Tehadap Metode Pembelajaran

\begin{tabular}{ccc}
\hline Bentuk Pernyataan & Persentase (\%) & Sikap \\
\hline \multirow{nyy}{*}{+} & $\mathrm{SS}+\mathrm{S}$ & Positif \\
\cline { 2 - 3 } & $\mathrm{TS}+\mathrm{STS}$ & Negatif \\
\hline \multirow{2}{*}{} & $\mathrm{SS}+\mathrm{S}$ & Negatif \\
\hline
\end{tabular}

Dari tabel 6 menunjukan sikap siswa terhadap keseluruhan pernyataan bersikap positif, pada tabel 7 menunjukan siswa bersikap positif pada pernyataan angket yang berbentuk pernyatan positif dan bersikap negatif pada bentuk pernyataan negatif, dan pada tabel 8 menunjukan rata-rata sikap yaitu Hampir setengahnya bersikap kearah positif. Dari ketiga analisis ter sebut ternyata siswa bersikap sebagian besar positif dan hampir setengahnya negatif, sehingga didapat siswa bersikap positif terhadap metode pembelajaran inquiri.

\section{Analisis Korelasi Data Hasil Angket dan Data Hasil Indeks Gain}

Analisis ini digunakan untuk mengetahui besar pengaruh yang diperoleh dari hasil perlakuan, data angket dirubah dahulu menjadi kuantitatif. Koefisien korelasi menurut Nugraha (Rahayu, 2009:32) memiliki interpretasi sebagai berikut

Tabel 13. Interpretasi Kefisien Korelasi

\begin{tabular}{cl}
\hline Koefisien Korelasi $(\boldsymbol{\rho})$ & \multicolumn{1}{c}{ Interpretasi } \\
\hline$\rho=-1$ & Korelasi negatif sempurna \\
\hline$-1<\rho \leq-0.80$ & Korelasi negatif tinggi sekali \\
\hline$-0.80<\rho \leq-0.60$ & Korelasi negatif tinggi \\
\hline$-0.60<\rho \leq-0.40$ & Korelasi negatif sedang \\
$-0.40<\rho \leq-0.20$ & Korelasi negatif rendah \\
\hline$-0.20<\rho<0$ & Korelasi negatif rendah sekali \\
\hline$\rho=0$ & Tidak mempunyai korelasi linear \\
\hline $0<\rho<0.20$ & Korelasi rendah sekali \\
\hline $0.20 \leq \rho<0.40$ & Korelasi rendah \\
\hline $0.40 \leq \rho<0.60$ & Korelasi sedang \\
\hline $0.60 \leq \rho<0.80$ & Korelasi tinggi \\
\hline $0.80 \leq \rho<1$ & Korelasi tinggi sekali \\
\hline$\rho=1$ & Korelasi sempurna \\
\hline
\end{tabular}

Tabel 9 menunjukan korelasi sebesar -0,087 dan jika diinterpretasikan ke tabel 13 menujukan hubungan yang negatif rendah sekali atau lemah sekali. Dan jika dihitung besar pengaruh diperoleh $8,7 \%$. Hal ini yang diasumsikan sesuai dengan hasil peningkatan yang berbeda pada indeks gain yang diperoleh yaitu 1 orang yang memperoleh peningkatan tinggi, Yang artinya bahwa siswa yang menggunakan métode pembelajaran inquirí mengalami peningkatan dibanding yang menggunakan métode konvensional terhadap kemampuan berpikir kreatif matematik. Hasil penelitian ini sejalan dengan hasil penelitian Nurman tambunan tahun 2016 bahwa minat belajar terhadap kemampuan berpikir kreatif matematis siswa. Penelitian lain yang hasilnya sama oleh Irma Idris tahun 2014 dengan judul pengaruh model pembelajaran 
inqury terhadap kemampuan berpikir kreatif siswa di jenjang SMA bahwa terdapat pengaruh yang signifikan model pembelajaran inqury terhadap kemampuan berpikir kreatif siswa dengan nilai kelas eksperimen rata-rata sebesar 73, 35 dan kelas kontrol rata-rata sebesar 58,15

\section{KESIMPULAN}

Berdasarkan hasil peneletian dan analisis yang dilakukan mengenai metode pembelajaran inquiri terhadap kemampan berpikir kreatif matematik siswa SMA dapat disimpulkan yaitu : (1) metode pembelajaran inquiri memiliki peningkatan kemampuan berpikir kreatif matematik siswa SMA; (2) Metode pembelajran inquiri memiliki pengaruh terhadap kemampuan berpikir kreatif matematik siswa SMA; (3) Siswa bersikap positif terhadap metode pembelajaran inquiri.

Berdasarkan kesimpulan diatas, maka penulis mengemukakan saran yaitu: 1) Dalam proses pembelajaran guru hendaknya menggunakan metode inquiri supaya siswa terbiasa dan pembelajaran akan lebih bermakna karena siswa mengalami sendiri sebagian dari proses pengalaman karena pembelajaran berpusat pada siswa; 2)Untuk menerapkan metode pembelajaran inquiri hendaknya guru memperhatikan kemampuan awal (entri behavior) yang dimiliki siswa sehingga siswa tidak mengalami kesulitan dalam proses pembelajaran berlangsung.

\section{DAFTAR PUSTAKA}

Arikunto, Suharsimi. (2010). Prosedur Penelitian Suatu Pendekatan Praktik. Jakarta :RinekaCipta.

Idris, Irma .(2014). Pengaruh Model Pembelajaran Inkuiri Terhadap Kemampuan Berpikir Kreatif Siswa. Jakarta: Fakultas Ilmu Tarbiyah dan Keguruan UIN Syarif Hidayatullah,

Michalko,michael.(2010). Cracking Creativity the secrets of Creative Genius Buisness, Education and Personal. Yogyakarta: Andi.

Nugroho,yohanes anton.(2011).It's Easy...Olah Data dengan SPSS.Yogyakarta:PT. Skripta Media Creative.

Partino dan Idrus.(2010).Statistik Deskriptif. Yogyakarta: Safiria Insania Press.

Rahayu, Sri.(2006).Pengaruh Model Pembelajaran Kooperatif Tipe Jigsaw Terhadap Kemampuan Berpikir Kreatif Siswa dalam Pembelajaran matematik.Skripsi Pendidikan pada FKIP UNSUR : tidak diterbitkan.

Sumiati dan Asra.(2007). Metode Pembelajaran. Bandung: CV Wacana Prima.

Tambunan, Nurma .(2016). Pengaruh Strategi Pembelajaran Dan Minat Belajar Terhadap Kemampuan Berpikir Kreatif Matematis Siswa. Jurnal Formatif 6(3): 207-219, 2016, from https://journal.lppmunindra.ac.id/index.php/Formatif/article/viewFile/993/929

Undang-Undang Republik Indonesia Nomor 20 Tahun 2003, Sistem Pendidikan Nasional. 